\section{In-row Distances and Nitrogen Fertilization Programs for 'Tasti-Lee' Specialty Tomato}

\author{
Bielinski M. Santos ${ }^{1}$, John W. Scott, and \\ Maricruz Ramírez-Sánchez
}

\begin{abstract}
ADDITIONAL INDEX WORDS. Lycopersicum esculentum, crop nutrition, soil fertility, best management practices, plant spacing

Summary. 'Tasti-Lee'TM ('Fla. 8153') is the first tomato (Solanum lycopersicum) released in Florida exclusively for the premium specialty market, with characteristic superior flavor and elevated lycopene concentration. Research was conducted to determine the appropriate nitrogen $(\mathrm{N})$ fertilization and in-row distances for 'TastiLee' tomato and thus improving the opportunities for successful adoption for this cultivar. Three $\mathrm{N}$ fertilization programs and two in-row distances were tested. Total $\mathrm{N}$ rates $(204,239$, and $274 \mathrm{lb} /$ acre) were the result of the combination of $50 \mathrm{lb} /$ acre of $\mathrm{N}$ during prebedding plus each of the following drip-applied $\mathrm{N}$ fertilization programs: 1) 1.5 and $2.0 \mathrm{lb} /$ acre per day from 1 to 4 weeks after transplanting (WAT) and 5 to $12 \mathrm{WAT}$, respectively; 2 ) $1.5,2.0$, and $2.5 \mathrm{lb} /$ acre per day during 1 to 2 WAT, 3 to 4 WAT, and 5 to 12 WAT; and 3 ) $1.5,2.5$, and $3.0 \mathrm{lb} /$ acre per day during 1 to 2 WAT, 3 to 4 WAT, and 5 to 12 WAT, respectively. In-row distances were 18 or 24 inches between plants, providing 5808 and 4356 plants/acre. Early and total marketable yields of 'Tasti-Lee' tomato were influenced by in-row distances and $\mathrm{N}$ fertilization programs, but not by their interaction. The highest early marketable fruit yield was found in plots treated with the highest $\mathrm{N}$ rate among fertilization programs $(+6 \%)$, and in plots planted 18 inches apart $(+7 \%)$ in comparison with the lowest $\mathrm{N}$ rate and the 24 -inch spacing. Tomato plots treated with the highest $\mathrm{N}$ rate $(274 \mathrm{lb} / \mathrm{acre})$ resulted in the largest total marketable yield $(+8 \%)$. Among the in-row distances, when plants were transplanted 18 inches apart, tomato total marketable yield increased by $18 \%$ compared with 24 inches between plants.
\end{abstract}

$\mathrm{F}$ lorida is the leading tomatoproducing state in the United States. In $2008, \approx 32,000$ acres were planted and gross sales were $\$ 622$ million (U.S. Department of Agriculture, 2009a). Currently, tomato growers in Florida face multiple challenges to improve sustainability and profitability. Three of those challenges are: 1) accessing premium cultivars with enhanced fruit quality and human nutritional properties; 2 ) determining appropriate fertilization practices to reduce nutrient leaching to groundwaters in sandy soils; and 3 ) improving cultural management (e.g., in-row spacing) to maximize land use in a state where a great deal of valuable agricultural land has been devoted to urbanization.

'Tasti-Lee'TM ('Fla. 8153') is the first fresh-market tomato hybrid released in Florida for the premium specialty market (Scott et al., 2008).

Gulf Coast Research and Education Center, IFAS, University of Florida, FL

We thank Humberto Moratinos, Elizabeth Golden, and Kathy Provenzano for their contribution during this research.

'Corresponding author. E-mail: bmsantos@ufl.edu.
It has high lycopene content and an attractive, deep red interior color due to the crimson gene (Thompson et al., 1965). Lycopene comprises between $80 \%$ and $90 \%$ of the carotenoids present in ripe tomatoes (Shi and LeMaguer, 2000). In raw and cooked tomatoes, the lycopene content obtained by Hart and Scott (1995) was 2.9 and $3.7 \mathrm{mg} /$ $100 \mathrm{~g}$, respectively, which was significantly higher than current cultivars. According to Clinton (1998), more than $80 \%$ of the lycopene consumed in the United States was derived from tomato, revealing its importance in the diet of Americans. 'Tasti-Lee' fruit flavor was superior to most commercially available tomato cultivars based on the results of sensory panels and samplings from field trials (Scott et al., 2008). Environmental conditions have a large impact on tomato flavor, and the strength of this hybrid is its ability to produce fruit with improved flavor under a wide range of growing conditions. This feature, along with reliable yields of firm, marketable fruit, should allow for branding of vine ripe harvested fruit with consistent quality. Recent observations have shown that 'Tasti-Lee' could be a valuable cultivar, not only for open field production, but also under protected structures.

Studies are needed to determine the most suitable production practices, such as $\mathrm{N}$ fertilization and inrow distances, to maximize yields of this cultivar. Tomato production in west-central and southwestern Florida occurs in sandy soils, which are characterized by rapid water infiltration, high water tables, and very low organic matter. Nitrate, one of the main forms of $\mathrm{N}$ in the soil, leaches rapidly to subsurface waters and enters bodies of water as contaminants, affecting aquatic life throughout the state (Carpenter et al., 1998; Florida Springs Task Force, 2000). In addition to environmental benefits of using appropriate $\mathrm{N}$ rates, fertilizer prices have increased significantly over the last few years (U.S. Department of Agriculture, 2009b), which forced the tomato industry to reevaluate current rates in an attempt to reduce production costs.

Nitrogen is the most applied nutrient on per weight basis in tomato and is mostly primarily injected daily through drip irrigation lines. Recent surveys throughout Florida found that $\mathrm{N}$ rates vary greatly across tomato farms, depending on soil characteristics, irrigation scheduling,

\begin{tabular}{llll}
\hline $\begin{array}{l}\text { Units } \\
\begin{array}{l}\text { To convert U.S. to SI, } \\
\text { multiply by }\end{array}\end{array}$ & U.S. unit & SI unit & $\begin{array}{l}\text { To convert SI to U.S., } \\
\text { multiply by }\end{array}$ \\
\hline 0.4047 & acre $(\mathrm{s})$ & $\mathrm{ha}$ & $2.471 \mathrm{l}$ \\
254.0000 & acre-inch/acre & $\mathrm{m} \cdot \mathrm{ha}^{-1}$ & 0.0039 \\
0.3048 & $\mathrm{ft}$ & $\mathrm{m}$ & 3.2808 \\
3.7854 & gal & $\mathrm{L}$ & 0.2642 \\
9.3540 & gal/acre & $\mathrm{L} \cdot \mathrm{ha}^{-1}$ & 0.1069 \\
2.54 & inch(es) & $\mathrm{cm}$ & 0.3937 \\
1.1209 & lb/acre & $\mathrm{kg} \cdot \mathrm{ha}^{-1}$ & 0.8922 \\
0.1 & $\mathrm{ppm}$ & $\mathrm{mg} / 100 \mathrm{~g}$ & 10 \\
1 & $\mathrm{ppm}$ & $\mathrm{mg} \cdot \mathrm{L}^{-1}$ & 1 \\
2.2417 & ton(s)/acre & $\mathrm{t} \cdot \mathrm{ha}^{-1}$ & 0.4461
\end{tabular}


and production region, fluctuating between 250 and $400 \mathrm{lb} /$ acre of $\mathrm{N}$. Previous research has revealed the variability of tomato responses to $\mathrm{N}$ rates and sources. Sainju et al. (2000), working in a sandy loam, found that a rate of $80 \mathrm{lb} /$ acre of $\mathrm{N}$ was as effective as $160 \mathrm{lb} /$ acre of $\mathrm{N}$. In California, seasonal application rates are between 150 and $350 \mathrm{lb} /$ acre of $\mathrm{N}$ for staked tomatoes (LeStrange et al., 2000). Végh et al. (2009) reported that use of a combination of slow- and fastrelease $\mathrm{N}$ fertilizers, and the rate and timing of their application, could prevent $\mathrm{N}$ leaching even in sandy soils. In Florida, current recommendations suggest that $\mathrm{N}$ fertilization should be about $200 \mathrm{lb} /$ acre for a 12-week season, using up to $70 \mathrm{lb} /$ acre of preplant $\mathrm{N}$ and the rest applied through drip lines (Olson et al., 2006). The seasonal distribution of this rate is $1.5,2.0,2.5$, and $2.0 \mathrm{lb} /$ acre per day of $\mathrm{N}$ for weeks 1 to 2 WAT, 3 to 4 WAT, 5 to 11 WAT, and 12 WAT, respectively. However, this recommendation does not distinguish between cultivars for mature-green harvest and premiummarket tomatoes, such as 'Tasti-Lee', which might affect yields per fruit category.

Previous studies discussed the different responses of vegetable crops to spatial distribution and in-row distances. In pepper (Capsicum annuum), Ortega et al. (2004) reported that fruit number and weight per plant decreased and yield per area improved with increased plant populations. West and Peirce (1988), examining effects of tomato planting densities on early and total yields, found that there was a significant density effect on each tested cultivar, where yields increased as densities decreased. Kemble et al. (1994) indicated that in-row distances between 12 and 30 inches caused no significant marketable yield differences of two determinate tomato cultivars. In contrast, Saglam and Yazgan (1995) determined that maximum tomato yields increased with density. These diverse findings suggested that research needs to be conducted to determine the appropriate in-row distance to maximize 'Tasti-Lee' yield potential. The objective of this study was to determine the most appropriate $\mathrm{N}$ fertilization program and inrow distances to maximize yields of 'Tasti-Lee' specialty tomato.

\section{Materials and methods}

Two field trials were conducted in the Fall 2006 and Spring 2007 at the Gulf Coast Research and Education Center of the University of Florida in Balm. The soil at the experimental site is classified as a Myakka fine sand siliceous hyperthermic Oxyaquic Alorthod with $1.5 \%$ organic matter and a $\mathrm{pH}$ of 7.3. Planting beds were preformed with a standard bedder and were 32 inches wide at the base, 28 inches wide at the top, 8 inches high, and spaced $5 \mathrm{ft}$ apart on centers. Finished beds were fumigated with methyl bromide plus chloropicrin $(67: 33, \mathrm{v} / \mathrm{v})$ at a rate of $175 \mathrm{lb} / \mathrm{acre}$ applied through three chisels spaced 12 inches apart, which delivered fumigant 6 inches deep to eliminate soilborne diseases, nematodes, and weeds in the soil. Soil fumigation occurred 3 weeks before transplanting. Within 1 min after fumigation, a drip irrigation tubing $(0.45 \mathrm{gal} / \mathrm{min}$ per $100 \mathrm{ft}$ of bed; T-Systems International, San Diego) was placed in all plots, regardless of irrigation program, 1 inch deep down the center of the bed, and planting beds were covered with 1-mil-thick silver on black mulch.

'Tasti-Lee' tomato seedlings in the four true-leaf stage ( 8 inches tall) were transplanted in single rows and 2 inches offset of bed centers. During the $3 \mathrm{~d}$ before transplanting, the water table was maintained at 24 inches below the bed tops by providing constant seepage irrigation to maintain the experimental site at field capacity. Depth of the water table was monitored every $3 \mathrm{~d}$ by installing observation wells (36 inches long by 4 inches in diameter) in the experimental site. After transplanting, a water volume of 0.4 acre-inches/acre per day (10,862 gal/acre per day) applied through seepage was used for the first $10 \mathrm{~d}$ after transplanting to establish young plants. This volume was constantly applied ( $24 \mathrm{~h}$ per day) through $\mathrm{l}$-ft-deep irrigation ditches oriented along the mulched beds. The experimental site was arranged to have one irrigation ditch for three planting beds. Drip irrigation was provided three times per day with irrigation cycles between 15 and $45 \mathrm{~min}$ (after $10 \mathrm{~min}$ of line pressurization) depending on the crop growth stage.

Six treatments resulted from arranging three $\mathrm{N}$ fertilization programs and two in-row distances. In-row distances were 18 and 24 inches between plants, which resulted in 5808 and 4356 plants/acre, respectively. Total $\mathrm{N}$ rates $(204,239$, and 274 $\mathrm{lb} /$ acre per season) were the result of the combination of preplant and drip-applied fertilizer. For preplant application, all experimental units received an $\mathrm{N}$ rate of $50 \mathrm{lb} / \mathrm{acre}$, using ammonium nitrate $(34 \% \mathrm{~N})$ as the $\mathrm{N}$ source, which was applied during prebedding. This fertilizer was broadcast on top of formed beds before bed pressing. Additionally, the drip-applied $\mathrm{N}$ rates were used: 154,189 , and 224 $\mathrm{lb} /$ acre per season. The partitioning of the drip-applied $\mathrm{N}$ rates for each fertilization program was as follows: 1) 1.5 and $2.0 \mathrm{lb} /$ acre per day from 1 to 4 WAT and 5 to 12 WAT, respectively, for a total of $154 \mathrm{lb} /$ acre of $\mathrm{N}$; 2) 1.5, 2.0 , and $2.5 \mathrm{lb} /$ acre per day during $\mathrm{l}$ to $2 \mathrm{WAT}, 3$ to 4 WAT, and 5 to 12 WAT, for $189 \mathrm{lb} /$ acre of $\mathrm{N}$; and 3) 1.5, 2.5 , and $3.0 \mathrm{lb} /$ acre per day during 1 to 2 WAT, 3 to 4 WAT, and 5 to 12 WAT, respectively, for $224 \mathrm{lb} /$ acre of $\mathrm{N}$. These periods of fertilization corresponded to the establishment, rapid growth, and flowering and fruiting stages of determinate tomato growth and development. The drip-applied $\mathrm{N}$ source was calcium nitrate $(9 \% \mathrm{~N})$ and other nutrients were applied under non-limiting conditions following current fertilization recommendations (Olson et al., 2006).

Other plant nutrients were injected using recommended sufficiency levels and current nutritional recommendations (Olson et al., 2006) during the last irrigation cycle (between 1 and $3 \mathrm{PM}$ ) three times per week with a hydraulic injector (Dosatron, Clearwater, FL). K was drip-injected to all plots three times per week using potassium chloride applied at rates of 1.5, 2.0 , and $2.5 \mathrm{lb} /$ acre per day from transplanting to 2 WAT, 3 to 5 WAT, and 6 to 12 WAT, respectively. Application of phosphorus $(\mathrm{P})$ and calcium (Ca) was not necessary because the experimental site had sufficient concentrations of these nutrients as indicated by soil tests conducted before planting. Tomato seasons were 12 weeks long from time of transplanting to last harvest. The crop was staked at 3 WAT and tied three times at $\approx 3,5$, and 8 WAT. Current recommendations for insect and disease control were followed (Olson et al., 2006). 
Treatments were arranged in a split-plot design, with $\mathrm{N}$ fertilization programs being the main plots. There were five and six replications in the Fall 2006 and Spring 2007, respectively. Experimental units had 15 tomato plants with a 5 -ft-long nontreated buffer zone at the end of each plot. Plant heights were determined at 3 and 6 WAT by measuring the vertical distance between bed tops and the highest opened growing point. Petiole samples were extracted at 8 WAT (1-inch fruiting stage) from between 10 and 15 mature petioles per plot collected from recently open mature leaves in each plot. The sap was extracted from 8 to $10(0.5$-inch long) petiole sections using a kitchen garlic press and samples were measured for nitrate- $\mathrm{N}\left(\mathrm{NO}_{3}-\mathrm{N}\right)$ concentrations with a $\mathrm{NO}_{3}$-ion analyzer (Cardy Meter, Horiba Group, Kyoto, Japan). Marketable tomato fruit were harvested twice (10 and 12 WAT) in the mature green stage and were graded following current market standards as extra-large, large, and medium fruit (Sargent et al., 2005). Fruit weights of the first harvest (10 WAT) were considered early yields. Resulting data were analyzed with analysis of variance to determine significance $(P<0.05)$ of effects of inrow distances, $\mathrm{N}$ fertilization programs, and their interactions on growth and yield variables (Statistix Analytical Software, Tallahassee, FL). Significant treatment means were separated using Fisher's protected least significant difference (LSD) test at the $5 \%$ level. For the economic analysis, the partial budget methodology was applied on the two most promising treatments (Perrin et al., 1988). This methodology uses a two-step procedure: 1) dominance analysis and 2) calculation of the marginal return rates (MRR). The dominance analysis consists of sorting treatments based on costs and listing them from the lowest to the highest, together with their respective net benefit. In moving from the lowest to the highest, any technology that costs more than the previous one but yields less net benefits is said to be "dominated" and can be excluded from further analysis (Evans, 2005; Perrin et al., 1988). The MRR indicates the percentage of net revenue gains of switching from one practice to another and it is calculated as follows: $\mathrm{MRR}=[$ (highest 1] $\times 100$.

\section{Results and discussion}

Data from the Fall 2006 and Spring 2007, seasons were combined because the season by treatment interactions for each variable were not significant. Tomato plant heights at 3 and 6 WAT were unaffected by main factors or the interaction between them. The average tomato plant heights were 32.4 and $59.5 \mathrm{~cm}$ at 3 and 6 WAT, respectively (Table 1 ). However, $\mathrm{N}$ fertilization programs influenced petiole sap $\mathrm{NO}_{3}-\mathrm{N}$ concentrations at 8 WAT, whereas in-row distances and the interaction between the two factors were not significant for this variable. The highest petiole sap $\mathrm{NO}_{3}-\mathrm{N}$ concentration was obtained with the fertilization program containing the highest $\mathrm{N}$ rate $(274 \mathrm{lb} / \mathrm{acre})$, while there were no differences when plots were treated with the other two $\mathrm{N}$ fertilization programs.

Early and total marketable yields of 'Tasti-Lee' tomato were influenced by in-row distances and $\mathrm{N}$ fertilization programs, but not by their interaction. There was no influence of individual factors on the early marketable yields of the extra-large or medium fruit sizes, averaging 13.7 and 0.6 tons/acre, respectively (Table 2 ). However, both factors individually affected early yields of the large fruit category. When tomato plants were planted 18 inches apart, large fruit net income $\div$ lowest net income $)-$

weight increased by $38 \%$ in comparison with the fruit yield in plots where plants were 24 inches apart. Similarly, when the applied $\mathrm{N}$ fertilization totaled $274 \mathrm{lb} /$ acre, large fruit early yield was increased by $41 \%$, as opposed to those obtained in plots applied with $239 \mathrm{lb} /$ acre of $\mathrm{N}$. The highest early marketable fruit yield was in plots treated with the highest $\mathrm{N}$ rate among fertilization programs, which increased by $\approx 6 \%$ in comparison with the other two $\mathrm{N}$ fertilization programs. Plots with tomato plants 18 inches apart produced almost $7 \%$ higher early fruit yield than plants at an in-row spacing of 24 inches.

'Tasti-Lee' tomato plots treated with the highest $\mathrm{N}$ rate $(274 \mathrm{lb} / \mathrm{acre})$ resulted in the largest total marketable yield, which was $\approx 8 \%$ higher than the other two $\mathrm{N}$ fertilization programs (Table 3). At the same time, there was no total marketable yield difference between $\mathrm{N}$ fertilization programs totaling 204 and $239 \mathrm{lb} /$ acre. Among in-row distances, total marketable yield increased by $18 \%$ when plants were spaced 18 inches apart in comparison with 24 inches between plants. Within fruit categories, the $\mathrm{N}$ fertilization programs influenced only large fruit total yield, which improved from 4.5 to 6.4 tons/acre when total $\mathrm{N}$ rate increased from 239 to $274 \mathrm{lb} /$ acre. In-row distances affected total weight of extra-large tomato fruit, declining from 26.7 tons/acre when plants were spaced 18 inches apart to 22.0 tons/ acre at 24 inches between plants.

Table 1. Effects of nitrogen $(\mathrm{N})$ fertilization programs and in-row distances on 'Tasti-Lee' tomato plant height at 3 and 6 weeks after transplanting (WAT) and on petiole sap nitrate- $\mathrm{N}\left(\mathrm{NO}_{3}-\mathrm{N}\right)$ concentration at $8 \mathrm{WAT}$ in 2006-07 at Balm, FL.

\begin{tabular}{|c|c|c|c|c|c|}
\hline \multicolumn{3}{|c|}{$\mathrm{N}$ fertilization programs $\mathrm{z}^{\mathrm{z}}$} & \multicolumn{2}{|c|}{ Plant ht } & \multirow{3}{*}{$\begin{array}{c}\text { Petiole sap } \mathrm{NO}_{3}-\mathrm{N} \\
\begin{array}{c}\text { 8 WAT } \\
(\mathrm{ppm})^{\mathrm{y}}\end{array}\end{array}$} \\
\hline Preplant N & Drip-applied $\mathbf{N}$ & Total $\mathrm{N}$ rate & $3 \mathrm{WAT}$ & $6 \mathrm{WAT}$ & \\
\hline \multicolumn{3}{|c|}{$(1 \mathrm{~b} / \mathrm{acre})^{\mathrm{y}}$} & \multicolumn{2}{|c|}{$(\mathrm{cm})^{\mathrm{y}}$} & \\
\hline 50 & 154 & 204 & 32.7 & 59.0 & $329 b^{x}$ \\
\hline 50 & 189 & 239 & 32.3 & 59.3 & $344 \mathrm{~b}$ \\
\hline 50 & 224 & 274 & 32.1 & 60.1 & $465 \mathrm{a}$ \\
\hline Significance & $(P<0.05)$ & & NS & NS & * \\
\hline \multicolumn{6}{|c|}{ In-row distances (inches) $)^{\mathrm{y}}$} \\
\hline 18 & & & 31.7 & 59.7 & 378 \\
\hline 24 & & & 33.0 & 59.2 & 381 \\
\hline Significance & $(P<0.05)$ & & NS & NS & NS \\
\hline
\end{tabular}

${ }^{\mathrm{z}}$ Fertilizer partitioning for each fertilization program was 1.5 and $2.0 \mathrm{lb} / \mathrm{acre}^{\mathrm{y}} \mathrm{N}$ per day from weeks 1 to 4 and 5 to $12 ; 1.5,2.0$, and $2.5 \mathrm{lb} /$ acre $\mathrm{N}$ per day; and $1.5,2.5$, and $3.0 \mathrm{lb} /$ acre $\mathrm{N}$ per day from weeks 1 to 2,3 to 4 , and 5 to 12 , respectively.

${ }^{\mathrm{y}} \mathrm{l} \mathrm{lb} /$ acre $=1.1209 \mathrm{~kg} \cdot \mathrm{ha}^{-1}, \mathrm{l} \mathrm{cm}=0.3937 \mathrm{inch}, \mathrm{l} \mathrm{ppm}=1 \mathrm{mg} \cdot \mathrm{L}^{-1}, \mathrm{l}$ inch $=2.54 \mathrm{~cm}$.

'Data examined with analysis of variance. When significant effects were found, means were separated with Fisher's protected least significant difference. Means followed by the same letter are not significantly different within a column

NS, *Not significant and significant at $P<0.05$, respectively. 
Table 2. Effects of nitrogen $(\mathrm{N})$ fertilization programs and in-row distances on 'Tasti-Lee' early tomato marketable yield ( 10 weeks after transplanting) per fruit category in 2006-07 at Balm, FL.

\begin{tabular}{|c|c|c|c|c|c|c|}
\hline \multicolumn{3}{|c|}{$\mathrm{N}$ fertilization programs ${ }^{\mathrm{z}}$} & \multicolumn{4}{|c|}{ Marketable tomato fruit categories ${ }^{y}$} \\
\hline Preplant N & Drip-applied N & Total $\mathrm{N}$ rate & Extra-large & Large & Medium & Total \\
\hline \multicolumn{3}{|c|}{$(1 \mathrm{~b} / \mathrm{acre})^{\mathrm{x}}$} & \multicolumn{4}{|c|}{$(\text { tons/acre })^{x}$} \\
\hline 50 & 154 & 204 & 13.5 & $2.1 b^{w}$ & 0.6 & $16.2 \mathrm{~b}$ \\
\hline 50 & 189 & 239 & 13.8 & $2.3 \mathrm{~b}$ & 0.6 & $16.7 \mathrm{~b}$ \\
\hline 50 & 224 & 274 & 13.8 & $3.3 \mathrm{a}$ & 0.6 & $17.7 \mathrm{a}$ \\
\hline Significance & $(P<0.05)$ & & NS & * & NS & * \\
\hline \multicolumn{7}{|c|}{ In-row distances (inches) ${ }^{\mathrm{x}}$} \\
\hline 18 & & & 13.7 & $2.9 \mathrm{a}$ & 0.7 & $17.3 \mathrm{a}$ \\
\hline 24 & & & 13.6 & $2.1 \mathrm{~b}$ & 0.4 & $16.2 \mathrm{~b}$ \\
\hline Significance & $(P<0.05)$ & & NS & * & NS & * \\
\hline
\end{tabular}

${ }^{\mathrm{z}}$ Fertilizer partitioning for each fertilization program was 1.5 and $2.0 \mathrm{lb} / \mathrm{acre}^{\mathrm{x}} \mathrm{N}$ per day from weeks 1 to 4 and 5 to $12 ; 1.5,2.0$, and $2.5 \mathrm{lb} /$ acre $\mathrm{N}$ per day; and $1.5,2.5$, and $3.0 \mathrm{lb} /$ acre $\mathrm{N}$ per day from weeks 1 to 2,3 to 4 , and 5 to 12 , respectively.

yxtra-large, large, and medium fruit sizes were between 7.3 and $8.8 \mathrm{~cm}$, between 6.4 and $7.2 \mathrm{~cm}$, and between 5.8 and $6.3 \mathrm{~cm}$ in equatorial diameter, respectively; $1 \mathrm{~cm}=0.3937$ inch.

${ }^{x} \mathrm{l} \mathrm{lb} /$ acre $=1.1209 \mathrm{~kg} \cdot \mathrm{ha}^{-1}, \mathrm{l}$ ton $/$ acre $=2.2417 \mathrm{t} \cdot \mathrm{ha}^{-1}, \mathrm{l}$ inch $=2.54 \mathrm{~cm}$.

"Data examined with analysis of variance. When significant effects were found, means were separated with Fisher's protected least significant difference. Means followed by the same letter are not significantly different within a column.

NS, *Not significant and significant at $P<0.05$, respectively.

Table 3. Effects of nitrogen $(\mathrm{N})$ fertilization programs and in-row distances on 'Tasti-Lee' total tomato marketable yield per fruit category in 2006-07 at Balm, FL.

\begin{tabular}{|c|c|c|c|c|c|c|}
\hline \multicolumn{3}{|c|}{$\mathrm{N}$ fertilization programs ${ }^{\mathrm{z}}$} & \multicolumn{4}{|c|}{ Marketable tomato fruit categories } \\
\hline Preplant N & Drip-applied $\mathbf{N}$ & Total $\mathrm{N}$ rate & Extra-large & Large & Medium & Total \\
\hline \multicolumn{3}{|c|}{$(1 \mathrm{~b} / \mathrm{acre})^{\mathrm{x}}$} & \multicolumn{4}{|c|}{$(\text { tons/acre })^{x}$} \\
\hline 50 & 154 & 204 & 23.9 & $4.7 \mathrm{~b}^{\mathrm{w}}$ & 1.9 & $30.5 \mathrm{~b}$ \\
\hline 50 & 189 & 239 & 24.5 & $4.5 \mathrm{~b}$ & 1.2 & $30.2 \mathrm{~b}$ \\
\hline 50 & 224 & 274 & 24.8 & $6.4 \mathrm{a}$ & 1.4 & $32.6 \mathrm{a}$ \\
\hline Significance & $(P<0.05)$ & & NS & * & NS & * \\
\hline \multicolumn{7}{|c|}{ In-row distances (inches) $)^{x}$} \\
\hline 18 & & & $26.7 \mathrm{a}$ & 5.4 & 1.4 & $33.5 \mathrm{a}$ \\
\hline 24 & & & $22.0 \mathrm{~b}$ & 4.9 & 1.5 & $28.4 \mathrm{~b}$ \\
\hline Significance & $(P<0.05)$ & & * & NS & NS & * \\
\hline \multicolumn{7}{|c|}{ 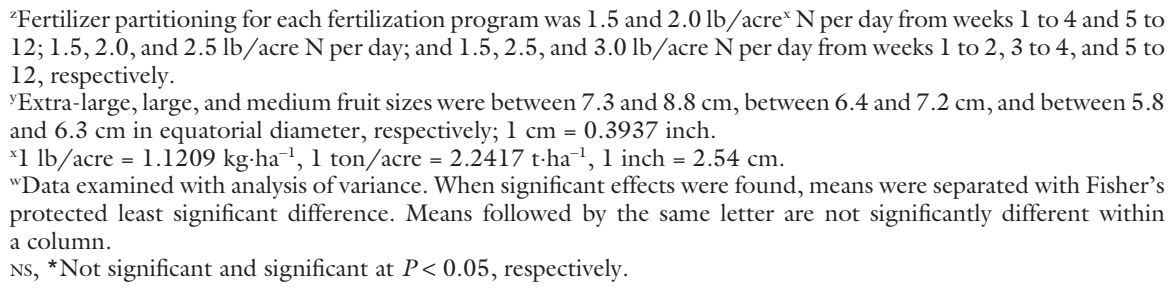 } \\
\hline
\end{tabular}

This data indicated that preplant application of $50 \mathrm{lb} /$ acre of $\mathrm{N}$ plus $224 \mathrm{lb} /$ acre through drip injection (a total $\mathrm{N}$ rate of $274 \mathrm{lb} /$ acre) improved early and total yields of 'Tasti-Lee' tomato in comparison with the other $\mathrm{N}$ fertilization programs. OzoresHampton et al. (2008) showed that a total $\mathrm{N}$ rate of $200 \mathrm{lb} /$ acre was not sufficient to maximize tomato yields, and $\mathrm{N}$ rates between 250 and $300 \mathrm{lb} /$ acre were needed. LeStrange et al. (2000) proposed using between 150 and $350 \mathrm{lb} /$ acre of $\mathrm{N}$ for tomato in
California. Santos (2009) reported that tomato plots receiving only seepage irrigation almost doubled their total yields when changing from 200 to $300 \mathrm{lb} /$ acre of $\mathrm{N}$. In contrast, current recommendations for Florida tomato production indicated that $\mathrm{N}$ fertilization should total $\approx 200 \mathrm{lb} /$ acre, with up to $70 \mathrm{lb} /$ acre of preplant $\mathrm{N}$ and the rest applied through drip lines (Olson et al., 2006).

It has been proposed that tomato may have differential seasonal responses to $\mathrm{N}$ fertilization programs.
Andersen et al. (1999) indicated that the $\mathrm{N}$ concentration in plant tissues increased linearly with $\mathrm{N}$ rates during the spring, but not during the fall season. However, in this study, $\mathrm{N}$ fertilization programs did not affect crop growth and yield between the spring and fall seasons. Similarly, other research suggested that the highest tomato yield was obtained when $40 \%$ of the total $\mathrm{N}$ rate was applied preplant (Locascio et al., 1997). That finding was different from the present investigation, where the highest yields were found when only $18 \%$ of the total $\mathrm{N}$ was preplantapplied.

In this study, the highest tomato yields were obtained in plots planted with at closest in-row spacing, equivalent to the highest planting density (5808 plants/acre). Similar results have been found in other crops. Ortega et al. (2004) found that higher pepper planting densities increased fruit yield per area mainly due to higher photosynthetically active radiation intercepted by the plant canopies. Motsenbocker (1996) determined that pepper plants growing at narrow distances produced the lowest biomass per plant, while having the highest fruit yield per area. In tomato, Papadopoulos and Ormrod (1990) estimated that high planting densities reduced individual fruit size but increased overall fruit yield per area. The differential effects of spatial arrangements on biomass allocation and plant architecture have also been studied in strawberry (Fragaria xananassa), where excessively wide spacing resulted in lower fruit number per plant compared with closer spacings (Hancock et al., 1984). Kogbe (1983) and Hanna et al. (1987) found that fruit number per plant increased with inrow distances in eggplant (Solanum melongena) and cucumber (Cucumis sativus), respectively.

Growers seeking to produce specialty 'Tasti-Lee' tomato will likely increase gross sales by modifying $\mathrm{N}$ fertilization programs and in-row distances in comparison with current recommended production practices. In this case, the dominance analysis indicated that the two most promising alternatives were the combination of an in-row distance of 18 inches and $274 \mathrm{lb} /$ acre of $\mathrm{N}$, and 24 inches inrow spacing and $239 \mathrm{lb} /$ acre of $\mathrm{N}$ (Table 4). The MRR rate for the 
Table 4. Comparison of partial budgets and marginal return rates (MRR) of combinations of in-row distances and nitrogen $(\mathrm{N})$ rates on 'Tasti-Lee' tomato marketable yield in 2006-07 at Balm, FL.

\begin{tabular}{|c|c|c|}
\hline Cost components $^{\mathrm{z}}$ & $\begin{array}{c}18 \text { inches and } 274 \\
1 \mathrm{~b} / \mathrm{acre} \text { of } \mathrm{N}^{\mathrm{y}}\end{array}$ & $\begin{array}{c}24 \text { inches and } 239 \\
1 \mathrm{~b} / \mathrm{acre} \text { of } \mathrm{N} \\
\end{array}$ \\
\hline \multicolumn{3}{|c|}{ Marketable yield } \\
\hline Fruit weight (tons/acre) $)^{y}$ & 17.7 & 16.7 \\
\hline Total gross revenue $(\$ / \text { acre })^{y}$ & 21,240 & 20,040 \\
\hline \multicolumn{3}{|c|}{ Variable costs } \\
\hline Transplants (\$ /acre) & 581 & 436 \\
\hline Fertilizer ( $\$ /$ acre $)$ & 822 & 717 \\
\hline Fruit picking ( $\$ /$ acre $)$ & 4814 & 4542 \\
\hline Total variable costs $(\$ /$ acre $)$ & 6217 & 5695 \\
\hline \multicolumn{3}{|c|}{ Revenues } \\
\hline Net income $(\$ /$ acre $)$ & 15,023 & 14,345 \\
\hline $\operatorname{MRR}(\%)$ & 4.72 & \\
\hline
\end{tabular}

${ }^{z}$ Total gross revenue $=$ fruit production multiplied by unit price at 2008 market prices; net income $=$ total gross revenue minus total variable costs; $\mathrm{MRR}=[$ (highest net income $\div$ lowest net income $)-1] \times 100$.

${ }^{\mathrm{y}} 1 \mathrm{inch}=2.54 \mathrm{~cm}, \mathrm{l} \mathrm{lb} / \mathrm{acre}=1.1209 \mathrm{~kg} \cdot \mathrm{ha}^{-1}, 1 \mathrm{ton} /$ acre $=2.2417 \mathrm{t} \cdot \mathrm{ha}^{-1}, \$ 1 /$ acre $=\$ 0.4047 / \mathrm{ha}$.

former was $4.72 \%$ higher than the MRR of the latter combination, which indicated that growers would earn $\$ 4.72$ extra for each $\$ 100$ of net profit by switching from 24 to 18 inches between tomato plants and increasing $\mathrm{N}$ fertilization from 239 to $274 \mathrm{lb} /$ acre. Because of the lack of reliable cost/benefit details on specialty tomato production in Florida, this economic analysis assumed the current prices for green mature tomato that might underestimate the actual retail price of specialty, vine-ripe fruit, such as 'Tasti-Lee' tomato. Under that scenario, the MRR of the proposed technological change for this type of tomato likely would increase.

\section{Literature cited}

Andersen, P.C., F.M. Rhoads, S.M. Olson, and K.D. Hill. 1999. Carbon and nitrogen budgets in spring and fall tomato crops. HortScience 34:648-652.

Carpenter, S.R., N.F. Caraco, D.L. Correll, R.W. Howarth, A.N. Sharpley, and V.H. Smith. 1998. Nonpoint pollution of surface waters with phosphorus and nitrogen. Ecol. Appl. 8:559-568.

Clinton, S.K. 1998. Lycopene: Chemistry, biology, and implications for human health and disease. Nutr. Rev. 56:3551 .

Evans, E.A. 2005. Marginal analysis: An economic procedure for selecting alternative technologies/practices. 29 Oct. 2008. <http://edis.ifas.ufl.edu/pdffiles/ FE/FE56500.pdf $>$.
Florida Springs Task Force. 2000. Florida's springs: Strategies for protection and restoration. 26 Nov. 2008. <http://www. dep.state.fl.us/springs/reports/index. htm>.

Hancock, J.F., J.W. Moon, and J.A. Flore. 1984. Within-row spacing and dry weight distribution in two strawberry cultivars. HortScience 19:412-413.

Hanna, H.Y., A.J. Adams, and R.N. Story. 1987. Increased yield in slicing cucumber with vertical training of plants and reduced plant spacing. HortScience 22: 32-34.

Hart, D.J. and K.J. Scott. 1995. Development and evaluation of an HPLC method for the analysis of carotenoids in foods, and the measurement of the carotenoids in foods, and the measurement of the carotenoid content of vegetables and fruits commonly consumed in the UK. Food Chem. 54:101-111.

Kemble, J.M., J.M. Davis, R.G. Gardner, and D.C. Sanders. 1994. Spacing, root cell volume, and age affect production and economics of compact-growth-habit tomatoes. HortScience 29:1460-1464.

Kogbe, J.O.S. 1983. Effects of spacing on the yield of local and exotic species of eggplant. Acta Hort. 123:291-297.

LeStrange, M., W.L. Schrader, and T.K. Hartz. 2000. Fresh-market tomato production in California. 11 Jan. 2010. <http:// ucanr.org/freepubs/docs/8017.pdf>.

Locascio, S.J., F.M. Rhoads, S.M. Olson, A.G. Smajstrla, and E.A. Hanlon. 1997. Nitrogen and potassium application scheduling effects on drip-irrigated tomato yield and leaf tissue analysis. HortScience 32:230-235.
Motsenbocker, C.E. 1996. In-row plant spacing affects growth and yield of pepperoncini pepper. HortScience 31:198-200.

Olson, S.M., W.M. Stall, M.T. Momol, S.E. Webb, T.G. Taylor, S.A. Smith, E.H. Simonne, and E. McAvoy. 2006. Tomato production in Florida, p. 407-426. In: S.M. Olson and E.H. Simonne (eds.). Vegetable production handbook for Florida, 2006-2007. Inst. Food Agr. Sci. Publ., Univ, Florida, Gainesville.

Ortega, R.G., M. Gutierrez, and J. Cavero. 2004. Plant density influences marketable yield of directly seeded 'Piquillo' pimiento pepper. HortScience 39:1584-1587.

Ozores-Hampton, M., E. Simonne, P. Gilreath, E. McAvoy, S. Sargent, D. McClure, T. Wilkes, and K. Morgan. 2008. Effect of nitrogen rates on yield and quality of tomato grown in the spring with sub-surface seepage irrigation. HortScience 43:1157-1158.

Papadopoulos, A.P. and D.P. Ormrod. 1990. Plant spacing effects on yield of the greenhouse tomato. Can. J. Plant Sci. 70:565-573.

Perrin, R., J. Anderson, D. Winkelmann, and E. Moscardi. 1988. From agronomic data to farmer recommendations: An economics training manual. CIMMYT Publ., Mexico City, Mexico.

Saglam, N. and A. Yazgan. 1995. The effects of planting density and the number of trusses per plant on earliness, yield and quality of tomato grown under unheated high plastic tunnel. Acta Hort. 412:258267.

Sainju, U.M., B.P. Singh, S. Rahman, and V.R. Reddy. 2000. Tillage, cover cropping, and nitrogen fertilization influence tomato yield and nitrogen uptake. HortScience 35:217-221.

Santos, B.M. 2009. Combinations of nitrogen rates and irrigation programs for tomato production in Spodosols. HortTechnology 19:781-785.

Sargent, S.A., J.K. Brecht, and T. Olczyk. 2005. Handling Florida vegetable series: Round and Roma tomato types. 21 Nov. 2009. <http://edis.ifas.ufl.edu/pdffiles / $\mathrm{VH} / \mathrm{VH} 07900 . \mathrm{pdf}>$.

Scott, J.W., E.A. Baldwin, H.J. Klee, J.K. Brecht, S.M. Olson, J.A. Bartz, and C.A. Sims. 2008. Fla. 8153 hybrid tomato: Fla. 8059 and Fla. 7907 breeding lines. HortScience 43:2228-2230.

Shi, J. and M. LeMaguer. 2000. Lycopene in tomatoes: Chemical and physical properties affected by food processing. Crit. Rev. Biotechnol. 20:293-334.

Thompson, A.E., M.L. Tomes, E.V. Wann, J.P. McCollum, and A.K. Stoner. 


\section{Research Reports}

1965. Characteristics of crimson tomato fruit color. Proc. Amer. Soc. Hort. Sci. 86: 610-616.

U.S. Department of Agriculture. 2009a. Vegetables: 2008 summary. 21 Nov. 2009. <http://usda.mannlib.cornell. edu/usda/current/VegeSumm/VegeSumm01-28-2009.pdf $>$.
U.S. Department of Agriculture. 2009b. U.S. fertilizer use and price. 11 May 2009. <http://www.ers.usda.gov/Data/Fertilizer Use>.

Végh, K.R., T. Szili-Kovács, K. Rajkai, I. Cserni, and T. Németh. 2009. Simulated and measured nitrogen conditions in to- mato culture. Commun. Soil Sci. Plant Anal. 40:610-619.

West, J. and L.C. Peirce. 1988. Yields of tomato phenotypes modified by planting density, mulch, and row covers. HortScience 23:321-324. 